\title{
AGE OF THE ROCKS OF ALASKA TERRITORY.
}

SrR, - Mr. Dall appears to me, in the extract of a letter of his, published in your last number, to base his determination of the Alaska: beds upon a species of Platanus found near Topanica, which he conconsiders to be undoubtedly Miocene. I fear this cannot be accepted as settling the question, seeing that Professor Heer has described a species of this genus ( $P$. Newberryana), from Nebraska, found in strata which he originally considered to be Miocene, but which Prof. Newberry has lately shown from the molluscan remains to be Cretaceous. Some additional evidence must be found before the age of these beds can be definitively fixed. The remarkable persistence of some of the generic forms of America from the Secondary down to the existing flora, as lately expounded by Professor Newberry, is a fact of great importance, especially when contrasted with the changes which have taken place in the Secondary and subsequent floras of Europe.

W. Carruthers.

\section{THE OLDEST BRITISH BELEMNITE.}

Sir,-The interesting notice by Mr. Tate, of his " little old" Belemnite from the Lower Lias beds, which yield Ammonites angulatus, may be a fit occasion for entreating the renewed attention of Palæontologists to the importance of this kind of research, unpromising though it be, for the origin of the "geno." My friend, Mr. C. Moore, besides placing at my disposal his whole collection of Belemnites, has sent me, among other rarities, a very small conical specimen from beds immediately above those which yield Ostrea liassica. This may be the young of the short conical form to which I have given the name of Belemnites calcar (Monograph of Belemnitidoe, pl. 11, fig. 4). The fossil described by Mr. Tate must certainly be distinguished from every variety of Belemnites clavatus; regarded as a young individual, it may with some confidence be thought likely to prove to be closely allied to $B$. pencillatus, which is by no means always deprived of lateral furrows, and is, in fact, a variable species (Monograph of Belemnitida, pl. 1., fig. 2, p. 35). I possess specimens of $B$. acutus and $B$. pencillatus, from the Lower Lias of Antrim. Belemnites dorsalis, of the Yorkshire Upper Lias, is certainly quite distinct.

OXFORD, April 4, 1869. John Phrmlips.

\section{THE OLDEST BRITISH BELEMNITE.}

Sr,--Mr. Tate's "oldest British Belemnite," described in the April number of the Geological Magazine, will have to yield the palm to an older one, which I found some years ago in the Insect beds (Ammonites planorbis zone of some geologists) at Binton, in Warwickshire. My friend Professor Phillips supposed that no Belemnites were known so low down, and I at once forwarded the specimen to him, and it is still in his possession. Unfortunately it is a mere fragment, consisting only of the phragmocone or chambered part of the shell, without the attached guard or sheath. The chambers, though crushed, from their size, indicate a tolerably largo 